\title{
Micro-morphological study of Evolvulus spp. (Convolvulaceae): the old world medicinal plants
}

\author{
Kanapol Ketjarun', George W. Staples ${ }^{2}$, Sasivimon C. Swangpol ${ }^{1}$ and Paweena Traiperm ${ }^{{ }^{*}}$
}

\begin{abstract}
Background: Several medicinal properties have been reported for plants in the genus Evolvulus, such as a brain tonic and antifungal from Evolvulus alsinoides, and a sedative and an anthelmintic from Evolvulus nummularius. Therefore, the correct identification of the source plants is critically important. The aim of this research was to investigate the micromorphology of two Evolvulus taxa used for herbal medicines compared with one worldwide ornamental species by using peeling, paraffin embedding, acetolysis, and SEM methods in order to support species identification.

Results: Our findings indicate that all taxa share several common features, such as a single layer of epidermis on both sides of leaf surfaces, sinuous anticlinal epidermal cell walls, anomocytic, paracytic or laterocytic stomata, and capitate glandular trichomes. Y-shaped hairs were found in two species but not in E. nummularius. Similarly, isobilateral mesophyll occurs in both E. alsinoides and Evolvulus glomeratus, but a dorsiventral mesophyll is present in E. nummularius. Stems consist of a single layer of epidermis, one to four chlorenchyma layers, one to seven layers of cortical cells and a bicollateral bundle with pith in the center. The seed coat epidermal cell shapes were irregular or polygonal with raised and undulated anticlinal boundaries, and folded or flattened to concave periclinal walls. Pollens of all taxa are monads, spheroidally shaped with 28-47 $\mu \mathrm{m}$ diameter, and 15-pantocolpate apertures type with microechinate ornamentation.
\end{abstract}

Conclusions: An identification key to species is constructed based on leaf anatomy and seed coat characters. This data can be used in other subjects such as pharmaceutical botany, organic chemistry, taxonomy and horticulture, in terms of species identification.

Keywords: Evolvulus alsinoides, Evolvulus nummularius, Evolvulus glomeratus, Leaf anatomy, Medicinal plant, Pollen, Seed coat

\section{Background}

The genus Evolvulus L. belongs to the family Convolvulaceae with two taxa (Evolvulus alsinoides (L.) L. and Evolvulus nummularius (L.) L.) that are used in Asian herbal medicine (Auddy et al. 2003; Chen 2007; Khare 2007; Ayyanar and Ignacimuthu 2011; Naikawadi et al. 2016), while Evolvulus glomeratus Nees \& Martius subsp. grandiflorus (Parodi) Ooststr. is a worldwide ornamental plant (Staples 2010). Some medicinal properties have been reported from E. alsinoides and E. nummularius.

\footnotetext{
*Correspondence: paweena.tra@mahidol.edu

1 Department of Plant Science, Faculty of Science, Mahidol University,

Rama VI Road, Ratchathewi, Bangkok 10400, Thailand

Full list of author information is available at the end of the article
}

Several substances were found in E. alsinoides, i.e., flavonols, flavonoids, alkaloids, cardiac glycosides, saponins, the alkanes pentatriacontane and triacontane, the phytosterol, $\beta$-sitosterol, phenolics, and tannins (Austin 2008; Naikawadi et al. 2016) and the plant is used as brain and memory tonic herb (Naikawadi et al. 2016), an anti-asthmatic, for treating uterine bleeding (Khare 2007), insanity, epilepsy and nervous debility (Auddy et al. 2003), for antibacterial, antifungal, and antiulcer properties (Austin 2008). The most common uses for medicinal applications are from India and surrounding regions (Manandhar 1985; Auddy et al. 2003; Khare 2007; Ayyanar and Ignacimuthu 2011; Naikawadi et al. 2016), however uses from some other countries in Southeastern Asia were 
found such as Taiwan (Chen 2007), Vietnam, Thailand (Austin 2008), and Philippines (Quisumbing 1978). In the New World people also use E. alsinoides, but there are fewer reports than the Old. Moreover, weak sedative and anthelmintic properties were reported in E. nummularius (Khare 2007; Ayyanar and Ignacimuthu 2011). Because of all these attributed properties, two Evolvulus species have been sold commonly via the internet as a powder used for brewing medicinal tea. Therefore, a proper identification is needed to correctly identify herbal ingredients used in remedies sold for home use.

Plant anatomy is one of the alternative ways to differentiate plant species (Stuessy 2009). Previous research on vegetative anatomy in Convolvulaceae has been reported to be useful for classification within several genera such as Argyreia Lour. (Sayeedud-Din 1953; Tayade and Patil 2012b; Staples et al. 2015), Calystegia R.Br. (Tayade and Patil 2012b), Cressa L. (Tayade and Patil 2012b), Evolvulus L. (Tayade and Patil 2012b; Harms 2014), Hewittia Wight \& Arn. (Tayade and Patil 2012b), Hildebrantia Vatke (Tayade and Patil 2012b), Ipomoea L. (SayeedudDin 1953; Tayade and Patil 2012b), Merremia Dennst. (Pisuttimarn et al. 2013), and Quamoclit Mill., (Sayeedud-Din 1953) which is now treated as a synonym of Ipomoea (Staples 2010). However, only one species of Evolvulus, E. alsinoides, has been investigated (Metcalfe and Chalk 1950; Tayade and Patil 2012b). Metcalfe and Chalk (1950) provided some diagnostic characters for the genus, such as two-armed or Y-shaped hair, cruciferous stomata type and cotyledons with secretory cells.

Hallier (1893) separated Convolvulaceae into two informal, non-taxonomic groups based on pollen type; Echinoconieae (grains with spines) and Psiloconiae (grains without spines, appearing 'smooth'). However, Erdtman (1952) used different terms to separate Convolvulaceae pollen into two types: Ipomoea type and other types. Meanwhile, pollen morphology of some groups of Convolvulaceae has been studied such as Convolvulaceae in southern new world (Tellería and Daners 2003), Bonamia Thouars (Lewis 1971), Convolvulus L. (Perveen et al. 1989; Menemen and Jury 2002), Cuscuta L. (Hamed 2005; Costea et al. 2008; Welsh et al. 2010; Dettke et al. 2014), Ipomoea (Hsiao and Kuoh 1995; Rajurkar et al. 2011; Robertson 1982), Odonellia K.R. Robertson (Robertson 1982) and Stylisma Raf. (Lewis 1971). A recent study of South American Convolvulaceae pollen classified Evolvulus pollen into microechinate-microgranulate pollen (Tellería and Daners 2003) and E. alsinoides has oval and tricolpate type (Singh and Dhakre 2010).

Seeds also offer useful taxonomic data. Convolvulaceae seeds provided some taxonomically significant characters to construct keys to some species in Egypt (Abdel Khalik and Osman 2007) and also some Ipomoea species (Rao and Leela 1993). The seed characters used to construct a key to species are shape, seed ornamentation, anticlinal boundaries and epidermal cell shape (Gunn 1969; Rao and Leela 1993; Abdel Khalik and Osman 2007). Seed morphology of Cuscuta and Ipomoea were studied by several researchers (Rao and Leela 1993; Abdel Khalik 2006; Hamed 2005; Abdel Khalik and Osman 2007).

In this study, leaf and stem micromorphological characters of three taxa in the genus Evolvulus are investigated and compared. In addition, seed and pollen morphology were investigated to support taxonomic identification because some medicinal preparations use the whole plant thus pollen and/or seeds could be present as well as leaves and stems. This approach maximizes the capacity for making an identification of any plant parts obtained from herbal medicaments. Furthermore, this research highlights the need for anatomical and micromorphological investigation of Evolvulus in tropical America, where about 100 species are known to occur (Junqueira and Simão-Bianchini 2006). So far as we know, there has been no intensive anatomical study done for the neotropical taxa of Evolvulus.

\section{Methods \\ Sample collection and herbarium specimen preparation}

Fresh materials were collected and voucher specimens were prepared as a standard method for plant taxonomy (Bridson and Forman 1999), and deposited at the Forest Herbarium (BKF) and Queen Sirikit Botanic Garden Herbarium (QBG) (Table 1).

\section{Anatomical study (peeling and paraffin methods)}

Leaf surfaces from five leaves in each taxon were scraped by a razor blade, stained with $1 \%$ Safranin-O and dehydrated by concentration series of ethanol. Leaf epidermal slides were mounted in DePeX mounting media. At least five leaves from each taxon were cut, dehydrated, infiltrated, and embedded in paraffin using a protocol modified from Johansen (1940). Sections were cut by sliding microtome (Leica SM2000R). Plant tissues were stained by Safranin-O and counterstained with Fast green and mounted in DePeX. Permanent slides were investigated and photographed under light microscopy using an Olympus BX43 with Olympus DP11 digital camera attached. The anatomical terminology used follows Metcalfe and Chalk (1950), Chen et al. (2008) and Pisuttimarn et al. (2013).

\section{Pollen morphological study}

Anthers from dried flower buds were treated by standard acetolysis method (Erdtman 1960). For light microscopy (LM), pollen was preserved in silicone oil. At least fifty grains of pollen were investigated randomly under LM. Pollen for scanning electron microscopy (SEM) was 
Table 1 List of specimens used in this study

\begin{tabular}{lll}
\hline Plant species & Localities & Collector number \\
\hline Evolvulus alsinoides var. decumbens & Thailand, Khon Kaen & KK \& PT 12 \\
& Thailand, Phetchaburi & KK \& PT 13 \\
E. glomeratus ssp. grandiflorus & Thailand, Bangkok & KK \& PT 11 \\
& Thailand, Khon Kaen & KK \& PT 14 \\
E. nummularius & Thailand, Bangkok & KK \& PT 10 \\
& Thailand, Khon Kaen & KK \& PT 15 \\
\hline
\end{tabular}

dried in the air, and coated with platinum and palladium $(\mathrm{Pt}+\mathrm{Pd})$ by ion sputter (Hitachi E102). Photographs were taken under SEM (Hitachi S-2500). Pollen terminology according to an illustrated handbook (Hesse et al. 2009) was used to describe pollen features.

\section{Seed morphology}

Mature seeds were fixed in $70 \%$ ethanol and cleaned by sonicator. Samples were fixed on a stub, coated with platinum and palladium $(\mathrm{Pt}+\mathrm{Pd})$ by ion sputter (Hitachi E102) and investigated by SEM (Hitachi S-2500). Descriptions follow Abdel Khalik and Osman (2007) and Juan et al. (1999).

\section{Results}

\section{Leaf and stem anatomy}

Leaf epidermal cell shapes were polygonal with sinuous or straight to curved anticlinal walls (Fig. 1a-c, g-i). Anisocytic, anomocytic, and paracytic stomatal types were found on both leaf surfaces, especially on the abaxial side (Fig. 1gi). Y-shaped hairs were present on both leaf surfaces of E. alsinoides collected from Khon Kaen and E. glomeratus, and the abaxial side of $E$. alsinoides from Phetchaburi (Fig. 1d, e, h-k). However, the hairs were absent in E. nummularius (Fig. 1c, f, i, l). Capitate glands were also present on both surfaces (Fig. 1e, f, j-l). The glands are composed of one small base cell, a single short stalk cell and two to four apical cells in a spheroidal or ellipsoid head (Fig. 1j, k).

\section{Leaf}

Blades in transverse section presented a single epidermal layer on both sides. Tanniniferous epidermal cells were detected only on the adaxial epidermis of E. alsinoides from Phetchaburi (Fig. 2a). Isobilateral mesophyll type was detected in E. alsinoides and E. glomeratus, while dorsiventral mesophyll type was restricted to E. nummularius (Fig. 2d-f). Leaf thickness is between 70-140 $\mu \mathrm{m}$, except in E. glomeratus: its leaves are thicker than the others with approximately 200-240 $\mu \mathrm{m}$ thickness (Fig. 2d-f). Vascular bundles at the midrib of all species are bicollateral type consisting of the sclerenchyma arch
(Fig. 2a-c). Leaf margins are rounded to slightly acute (Fig. 2g-i). Leaf characters of all species are summarized in Table 2.

\section{Stems}

As seen in transverse sections stems in all species are composed of a single epidermis with one to four layers of chlorenchyma cells. Evolvulus alsinoides is the only species that possesses the tanniferous cells in the epidermis. Cortex was restricted by one to seven parenchyma cell layers. Vascular tissues are the bicollateral bundle type with cylindrical xylem (Fig. 2j-o). Pith was observed at the center. All stem anatomical characters are summarized (Table 2).

\section{Pollen morphology}

All species share some common pollen characters i.e., monads, medium size and 15-pantocolpate apertures $(5$ polar $\times 5$ equatorial $\times 5$ polar arrangement of the colpi) (Fig. 3a-i). The length of polar axis (P) is between 27-45 $\mu \mathrm{m}$, whereas 28-47 $\mu \mathrm{m}$ in equatorial axis (E). Therefore, the $\mathrm{P} / \mathrm{E}$ ratio is calculated to be a spheroidal shape. Evolvulus alsinoides and E. nummularius have similar size; $27-33 \mu \mathrm{m}$ in polar axis and $28-33 \mu \mathrm{m}$ in equatorial axis: however E. glomeratus differs from the other two species by having 39-45 $\mu \mathrm{m}$ polar axis and 41-47 $\mu \mathrm{m}$ equatorial length. Pantocolpate apertures and microechinate ornamentation were recorded in all species (Fig. 3j-l) (Table 3).

\section{Seed morphology}

Seeds of two species studied (the seeds of E. glomeratus were not available) varied from 1-2 $\mathrm{mm}$ in length and 1-1.5 mm in width with yellow, orange, red or brown seed coat (Table 3 ). The seeds are glabrous. Seed shape was trigonous-ovoid with glabrous surface. Epidermal cell shapes were irregular or polygonal in both species with undulate and raised anticlinal boundaries. Periclinal cell walls were flattened to concave in E. nummularius and folded in E. alsinoides. All seed features are summarized in Table 3 (Fig. 4). 

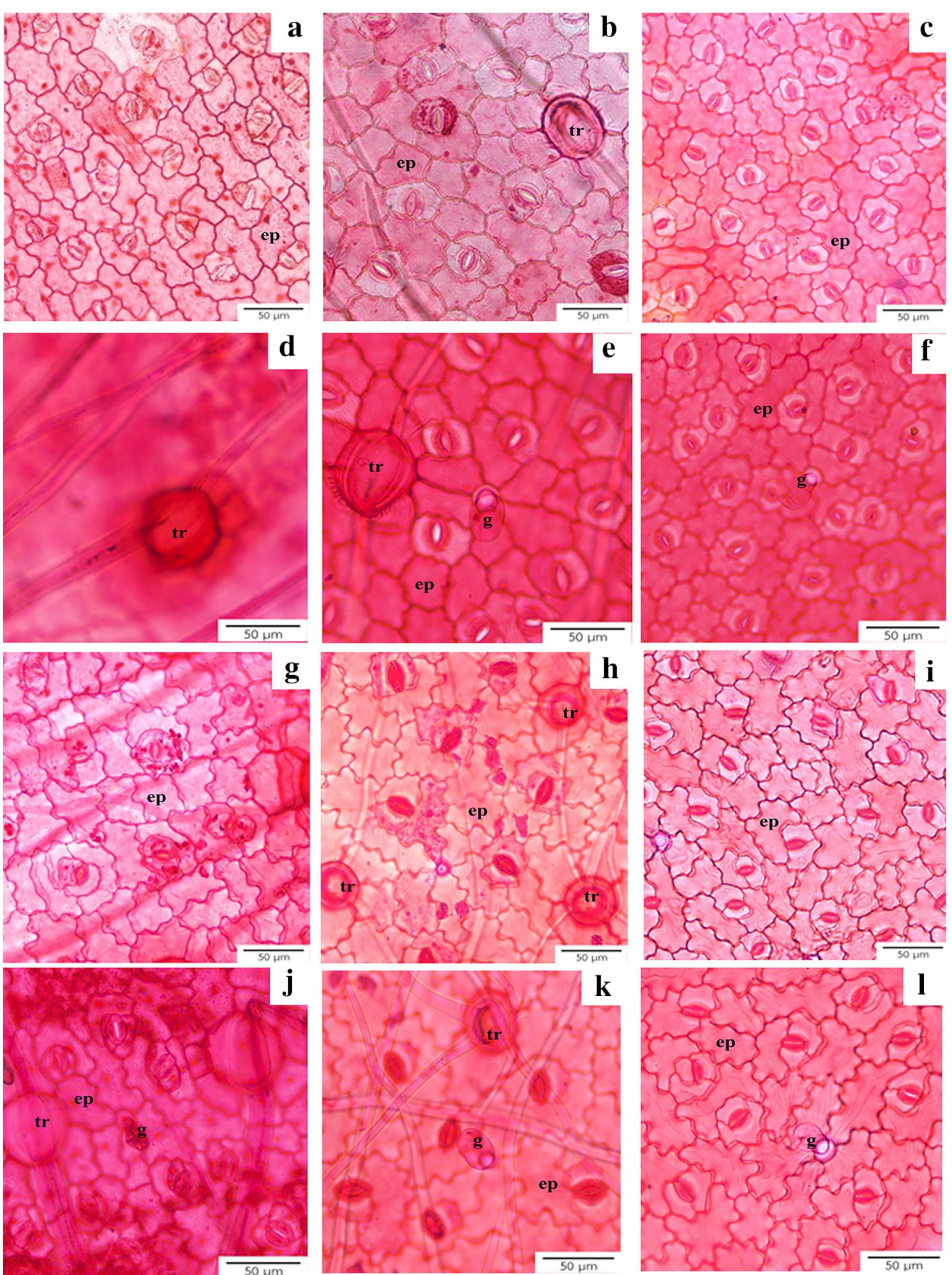

Fig. 1 Epidermis under LM. Sinuous or straight to curved anticlinal wall and stomata occurring at the adaxial surface of E. alsinoides (a), E. glomeratus (b) and E. nummularius (c). Y-shaped hair on adaxial surface of E. alsinoides from Khon Kaen (d). Y-shaped hair and capitate gland of E. glomeratus (e), capitate gland on leaf surface of E. nummularius (f). Sinuous or straight to curved anticlinal walls on abaxial epidermal layer of $E$. alsinoides ( $(\mathbf{g})$, $E$. glomeratus (h) and E. nummularius (i). Evolvulus alsinoides $(\mathbf{j})$ and E. glomeratus ( $\mathbf{k}$ ) possess the Y-shaped hairs and capitate glands, but E. nummularius (I) has no hairs. ep epidermis, tr trichome, $g$ capitate gland 

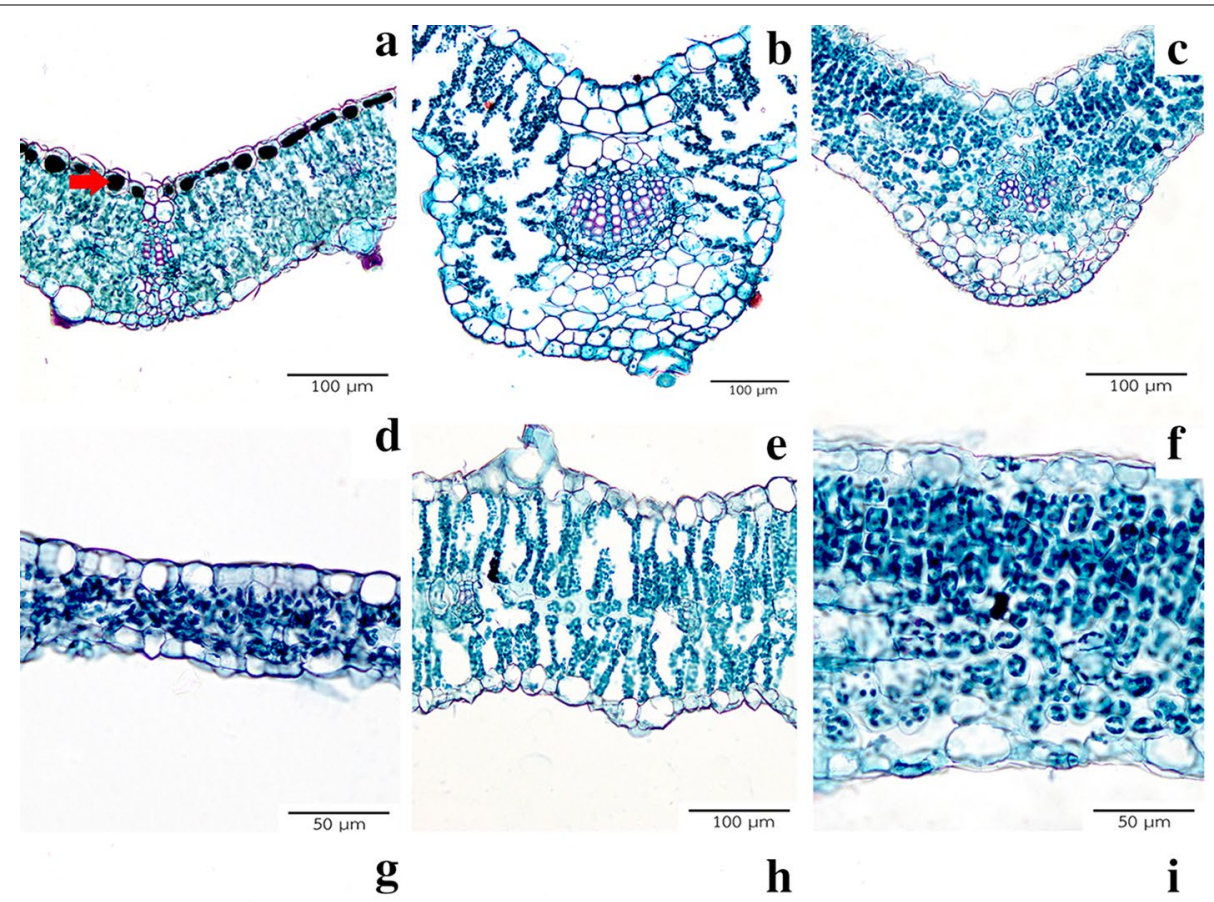

g

h
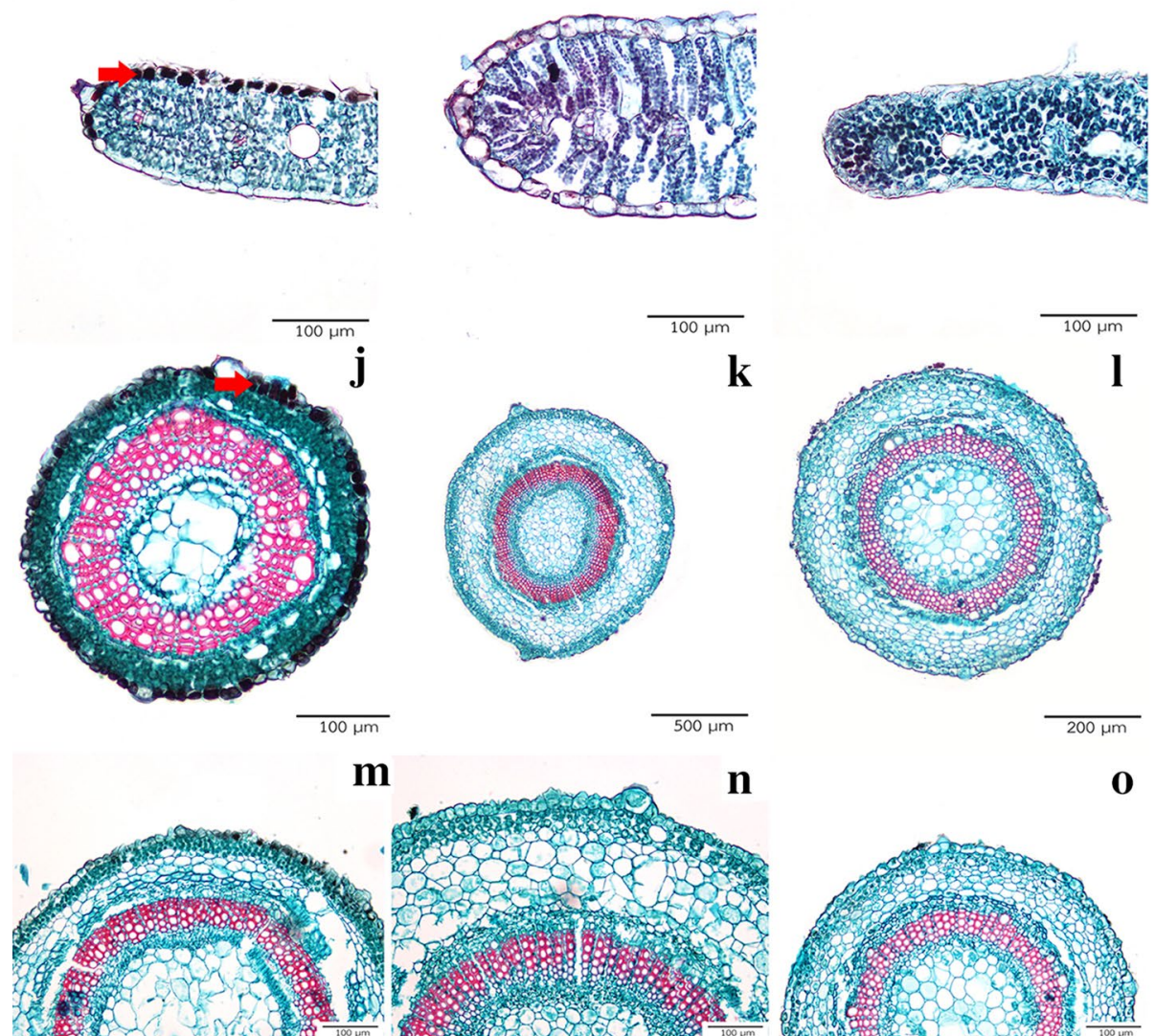

$\mathbf{n}$

$\mathbf{0}$

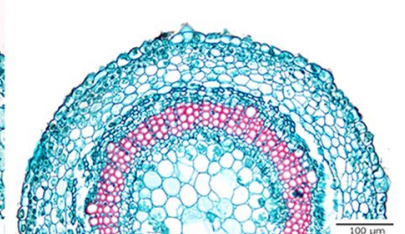

Fig. 2 Transverse sections of leaf and stem. A single epidermal layer and bicollateral vascular bundle of E. alsinoides (a), E. glomeratus (b) and E. nummularius (c). Tanniniferous epidermal cell is unique in E. alsinoides from Petchaburi (a, $\mathbf{g}$, j indicated by red arrows). Isobilateral mesophyll present in E. alsinoides (d) and E. glomeratus (e). Evolvulus nummularius showing dorsiventral mesophyll type (f). Rounded leaf margins of E. alsinoides ( $(\mathbf{g})$, E. glomeratus (h) and E. nummularius (i). Outline of stem in E. alsinoides (j), E. glomeratus $(\mathbf{k})$ and E. nummularius (I). Enlarged view to show the stem layers of E. alsinoides $(\mathbf{m})$, E. glomeratus (n) and E. nummularius (o) 
Table 2 Comparison of the leaf anatomy in three taxa

\begin{tabular}{|c|c|c|c|c|}
\hline $\begin{array}{l}\text { Plant taxa } \\
\text { Characters }\end{array}$ & $\begin{array}{l}\text { E. alsinoides var. decumbens } \\
\text { (KK \& PT 12) }\end{array}$ & $\begin{array}{l}\text { E. alsinoides var. decumbens } \\
\text { (KK \& PT 13) }\end{array}$ & $\begin{array}{l}\text { E. glomeratus ssp. } \\
\text { grandiflorus }\end{array}$ & E. nummularius \\
\hline \multicolumn{5}{|l|}{ Leaf epidermis } \\
\hline \multicolumn{5}{|l|}{ Adaxial surface } \\
\hline Cell shape & Polygonal & Polygonal & Polygonal & Polygonal \\
\hline Anticlinal cell wall & Sinuous or straight to curved & Sinuous or straight to curved & Sinuous or straight to curved & Sinuous or straight to curved \\
\hline Stomatal type & $\begin{array}{l}\text { Anisocytic, anomocytic and } \\
\text { paracytic }\end{array}$ & $\begin{array}{l}\text { Anisocytic, anomocytic and } \\
\text { paracytic }\end{array}$ & $\begin{array}{l}\text { Anisocytic, anomocytic and } \\
\text { paracytic }\end{array}$ & $\begin{array}{l}\text { Anisocytic, anomocytic and } \\
\text { paracytic }\end{array}$ \\
\hline Y-shaped hairs & Present & Absent & Present & Absent \\
\hline Capitate gland & Present & Present & Present & Present \\
\hline \multicolumn{5}{|l|}{ Abaxial surface } \\
\hline Cell shape & Polygonal & Polygonal & Polygonal & Polygonal \\
\hline Anticlinal cell wall & Sinuous or straight to curved & Sinuous or straight to curved & Sinuous or straight to curved & Sinuous or straight to curved \\
\hline Stomatal type & $\begin{array}{l}\text { Anisocytic, anomocytic and } \\
\text { paracytic }\end{array}$ & $\begin{array}{l}\text { Anisocytic, anomocytic and } \\
\text { paracytic }\end{array}$ & $\begin{array}{l}\text { Anisocytic, anomocytic and } \\
\text { paracytic }\end{array}$ & $\begin{array}{l}\text { Anisocytic, anomocytic and } \\
\text { paracytic }\end{array}$ \\
\hline Y-shaped hairs & Present & Present & Present & Absent \\
\hline Capitate gland & Present & Present & Present & Present \\
\hline \multicolumn{5}{|l|}{ Leaf transverse section } \\
\hline Epidermal layer & Single layer & Single layer & Single layer & Single layer \\
\hline Parenchyma at midrib & 2-4 layers & 2-4 layers & 4-5 layers & 3-7 layers \\
\hline Mesophyll & Isobilateral & Isobilateral & Isobilateral & Dorsiventral \\
\hline Midrib vascular bundle & Bicollateral type & Bicollateral type & Bicollateral type & Bicollateral type \\
\hline Leaf thickness $(\mu \mathrm{m})$ & $70-100$ & $70-100$ & $200-240$ & $120-140$ \\
\hline Leaf margins & Rounded to slightly acute & Rounded to slightly acute & Rounded to slightly acute & Rounded to slightly acute \\
\hline \multicolumn{5}{|l|}{ Stem transverse section } \\
\hline Epidermal layer & Single layer & Single layer & Single layer & Single layer \\
\hline Chlorenchyma layer & 1-3 layers & 2-4 layers & 2-4 layers & 2-4 layers \\
\hline Cortex & $1-3$ layers & $3-5$ layers & 5-7 layers & 5-7 layers \\
\hline Vascular bundle & Bicollateral type & Bicollateral type & Bicollateral type & Bicollateral type \\
\hline Pith & Present & Present & Present & Present \\
\hline
\end{tabular}

\section{Discussion}

This study provides for the first time comprehensive micro-morphological information for three Evolvulus taxa. Leaf and stem anatomical characters basically coincide with the descriptions of other Convolvulaceae species previously studied by Metcalfe and Chalk (1950).

General diagnostic characters for Evolvulus leaves on surface view are the sinuous or straight to curved anticlinal walls, anisocytic, anomocytic and paracytic stomatal types, the presence of Y-shaped hairs, and capitate trichomes. The presence of the anisocytic (or cruciferous) stomatal type corresponds to the previous report by Metcalfe and Chalk (1950). Most species have Y-shaped hairs on both sides of the leaves, except in E. nummularius. Furthermore, E. alsinoides from Phetchaburi has Y-shaped hairs on the abaxial surface only. The occurrence of Y-shaped hairs on both leaf surfaces was similar to the discovery of Metcalfe and Chalk (1950), and also matched with the study of Harms (2014) which recorded
Y-shaped hairs in three Evolvulus species found in Texas and New Mexico. The function of Y-shaped hairs might be functionally related to reduction in water loss for the plant because E. alsinoides is always found on limestone in a habitat which has intense insolation accompanied by low humidity and dry soils. These non-glandular trichomes cover up the guard cells in order to protect the plant from dessication. Metcalfe and Chalk (1950) mentioned the secretory cells found in the cotyledons of many genera including Evolvulus, but did not specify the type of cell. Capitate glandular trichomes were found in all three Evolvulus taxa, and here we describe this character in detail for the first time.

The characters of leaf transverse sections useful for species separation are as follows: the presence of tanniniferous epidermal cells; type of palisade mesophyll and leaf thickness. Evolvulus alsinoides from Phetchaburi is the only plant sample that presented a storage substance on the adaxial epidermal cells, coincident with Metcalfe and 

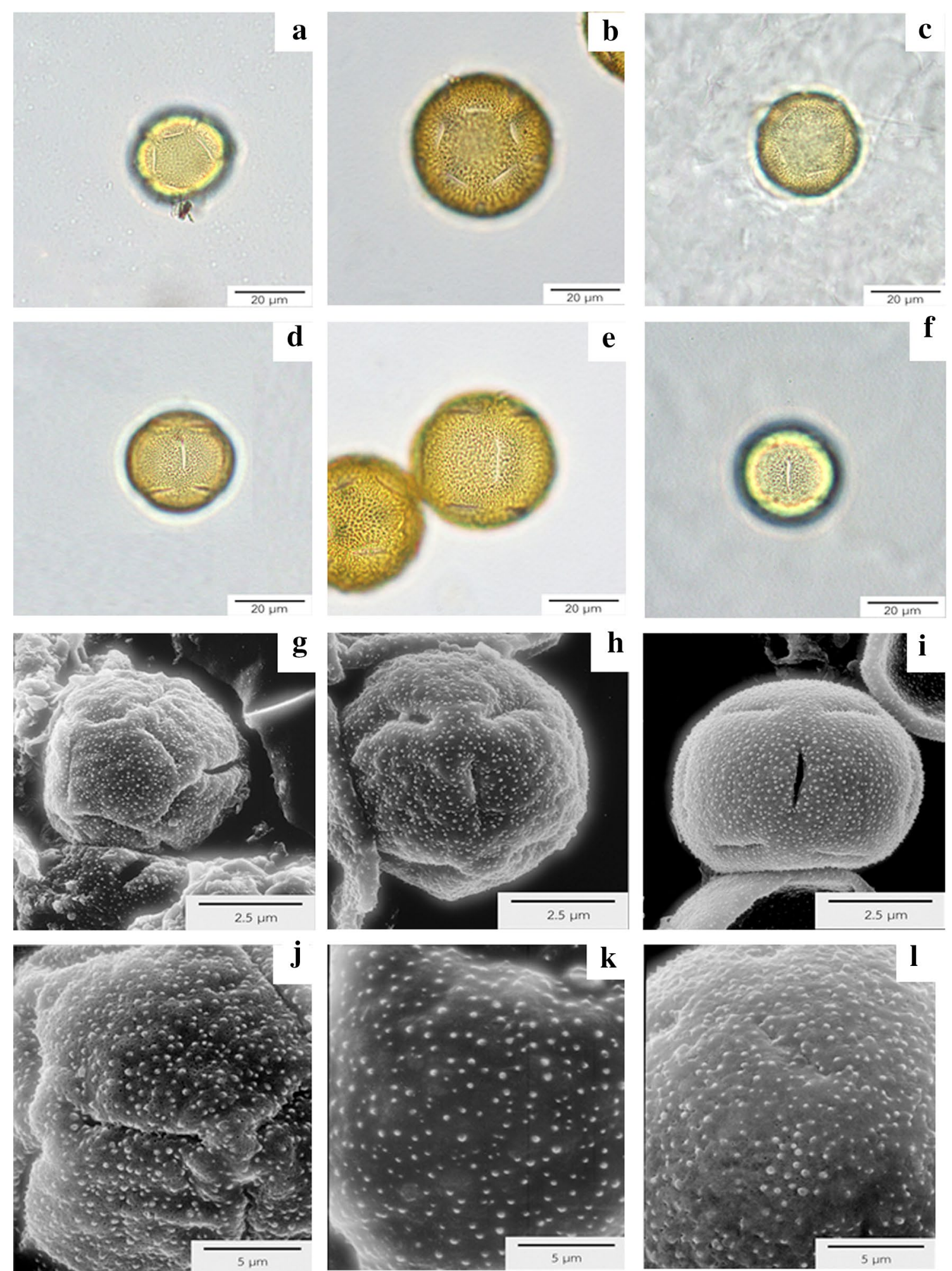

Fig. 3 Pollen under light microscopy (LM) and scanning electron microscopy (SEM). a-c Polar view under LM of E. alsinoides (a), E. glomeratus (b) and E. nummularius (c), which demonstrates the monad pollen unit and 5-pantocolpate apertures. $\mathbf{d}$-f Monad pollen under LM with 5-pantocolpate apertures at equatorial view of E. alsinoides (d), E. glomeratus (e) and E. nummularius (f). g-i SEM of E. alsinoides (g) in polar view, showing 5-pantocolpate apertures. Polar view under SEM of E. glomeratus (h), equatorial view of E. nummularius (i) presenting 5-pantocolpate apertures. j-I Microechinate ornamentation of E. alsinoides (j), E. glomeratus $(\mathbf{k})$ and E. nummularius (I) 
Table 3 Pollen and seed morphological characters in all taxa

\begin{tabular}{lllll}
\hline $\begin{array}{l}\text { Plant taxa } \\
\text { Characters }\end{array}$ & $\begin{array}{l}\text { E. alsinoides var. } \\
\text { decumbens (KK \& PT 12) }\end{array}$ & $\begin{array}{l}\text { E. alsinoides var. } \\
\text { decumbens (KK \& PT 13) }\end{array}$ & $\begin{array}{l}\text { E. glomeratus ssp. } \\
\text { grandiflorus }\end{array}$ & E. nummularius \\
$\begin{array}{l}\text { Pollen morphology } \\
\text { Pollen unit }\end{array}$ & Monad & Monad & Monad & Monad \\
$\begin{array}{l}\text { Size polar axis }(\mathrm{P})(\mu \mathrm{m}) \\
\text { Size equatorial axis }(\mathrm{E})(\mu \mathrm{m})\end{array}$ & $29-32$ & $27-33$ & $39-45$ & $28-33$ \\
Shape & $28-31$ & $29-33$ & $41-47$ & $28-33$ \\
Aperture & Spheroidal & Spheroidal & Spheroidal & Spheroidal \\
Ornamentation & 15 -pantocolpate & 15 -pantocolpate & 15 -pantocolpate & 15 -pantocolpate \\
Seed morphology & Microechinate & Microechinate & Microechinate & Microechinate \\
Shape & Ovoid & Ovoid & No material available & Broadly elliptic \\
Size & $1-1.5 \times 1-1.5$ & $1-1.5 \times 1-1.5$ & No material available & $1.5-2 \times 1-1.5$ \\
Color & Yellow/orange/red/brown & Yellow/orange/red/brown & No material available & Yellow/brown \\
Surface & Glabrous & Glabrous & No material available & Glabrous \\
Epidermal cell shape & Irregular, polygonal & Irregular, polygonal & No material available & Irregular, polygonal \\
Anticlinal boundaries & Undulate & Undulate & No material available & Undulate \\
Periclinal cell wall & Folded & Folded & No material available & Flattened to concave \\
\hline
\end{tabular}

Chalk (1950) treatment. Thai Evolvulus taxa showed both isobilateral and dorsiventral mesophyll types. Isobilateral type was found in E. alsinoides and E. glomeratus, while the dorsiventral type occurs in E. nummularius. Tayade and Patil (2012b) described a dorsiventral mesophyll for E. alsinoides from India, which is not congruent with our findings. The reason might be the differences between two populations of $E$. alsinoides from India and Thailand in terms of variability of anatomical features. It is also possible that Tayade and Patil (2012b) had another species entirely: there were no voucher specimens cited for the plants they studied, and thus we cannot be certain that our results are comparable with their findings.

According to the monograph by van Ooststroom (1934), E. alsinoides was separated into 15 varieties. It is possible that $E$. alsinoides collected from Phetchaburi might not be the same variety as the plant from Khon Kaen province as suggested by the differences of Y-shaped hairs as well as the storage epidermal cells and the mesophyll arrangement. Another possibility would be the environmental differences in two populations of $E$. alsinoides because $E$. alsinoides (KK \& PT 12) came from limestone area but $E$. alsinoides (KK \& PT 13) was collected from weedy place. The occurrence of Y-shaped hairs and dorsiventral mesophyll can clearly be used to separate $E$. nummularius from the others, while the other two species can be identified by leaf thickness. Evolvulus alsinoides has thinner leaves $(70-100 \mu \mathrm{m})$ than E. glomeratus $(200-240 \mu \mathrm{m})$. With sufficient fertilizer and water, cultivated plants are usually bigger than wild plants of the same species (Lau and Stephenson 1994) almost in all aspects as shown in leaf thickness from this study. Thus, a key to the species provided here has to be used with caution because the anatomical characters might be different from wild species. Presence of Y-shaped hair was also useful to distinguish the species of Evolvulus as was proposed recently by Harms (2014).

Stem anatomical characters are similar in all species; however, the stem diameter in E. glomeratus is bigger than the other two species. The presence of tanniferous and chlorenchyma cells in the stem has never been described previously. A bicollateral bundle is the typical type for the family Convolvulaceae as was formerly reported by Metcalfe and Chalk (1950) and Tayade and Patil (2012a).

Pollen characters of all taxa are quite similar in all aspects; therefore pollen morphology has low taxonomic value to identify Evolvulus taxa. The only one quantitative datum that can be used to separate E. glomeratus from other taxa was the pollen size. Evolvulus glomeratus possessed the largest pollen with $39-45 \mu \mathrm{m}$ in polar axis (length) and 41-47 $\mu \mathrm{m}$ in equatorial axis (width). Pollen ornamentation and apertures are consistent with the investigation of Tellaría and Daners (2003) which classified Evolvulus pollen into Type II with microechinate exine. In their study, three species of Evolvulus were examined i.e., E. arizonicus A. Gray, E. glomeratus Nees \& Mart. and E. sericeus Sw., therefore this investigation confirms the exine pattern of Evolvulus by having studied two more species in the genus. However, this current study disagrees with the reproductive biological examination of medicinal plant by Singh and Dhakre (2010) which recorded E. alsinoides pollen as tricolpate apertures and reticulate ornamentation. The photos of live plants shown in their paper looked quite different from $E$. alsinoides collected from Thailand. Sarma et al. (2007) have 

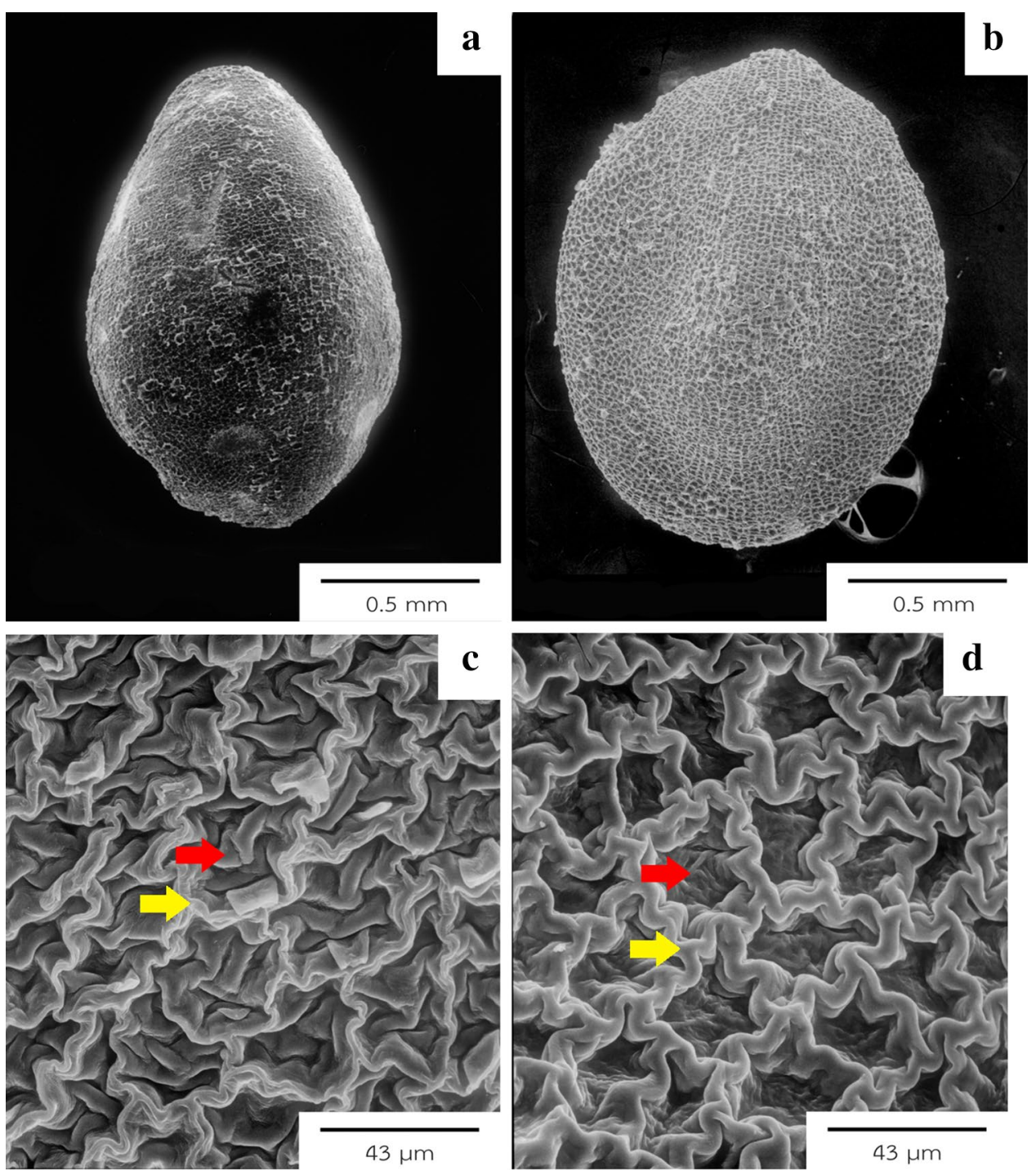

Fig. 4 Seed morphology from SEM. Glabrous and ovoid shaped seed of E. alsinoides (a) from Petchaburi, broadly ellipsoid seed with glabrous surface in E. nummularius (b), close up of E. alsinoides (c) from Khon Kaen, seed testa showing undulate anticlinal boundaries (yellow arrows) and folded periclinal cell wall (red arrows). Evolvulus nummularius (d) displayed undulate anticlinal boundaries with flat to concave periclinal cell wall

suggested that the pollinator of E. nummularius in India is a Graceful Awl snail (Lamellaxis gracile) on rainy days, while a honey bee (Apis cerana indica) is the pollinator on a sunny day. However, E. nummularius is not a native species in India. Therefore, the pollination relationships may not be typical for the native habitat in South America. Singh and Dhakre (2010) mentioned the honey bee as one of nine insect pollinators of E. alsinoides. From plant morphology, a snail should not be a pollinator for E. alsinoides and E. glomeratus because their flower position is not located close to the soil surface as it is for E. nummularius. Therefore, the honey bee and flies might be the pollinators of E. alsinoides and E. glomeratus.
Seed characters have taxonomic significance and can be used to construct a key to species. Periclinal walls differ between two taxa: folded in E. alsinoides and flat to concave in $E$. nummularius. The testal periclinal cell wall corresponded to that described by Abdel Khalik and Osman (2007).

\section{Conclusions}

From leaf anatomical characters, there are some taxonomic aspects to distinguish these three Evolvulus taxa, therefore a key to taxa based on leaf anatomy was constructed. 


\section{Key I to species: Leaf anatomical characters}

1. Leaf dorsiventral mesophyll type.

1. Leaf isobilateral mesophyll type

2. Leaf blade transverse section thin, less than or equal to $100 \mu \mathrm{m}$ thickness

E. alsinoides

2. Leaf blade transverse section thick, greater than or equal to $200-240 \mu \mathrm{m}$

E. glomeratus

Seed characters have taxonomic significance and can be used to construct a key to species.

\section{Key II to species: Seed morphological characters}

1. Testal periclinal cell wall folded

E. alsinoides

1. Testal periclinal cell wall flattened to concave

E. nummularius

This data serves as a base line to be used in other subjects such as taxonomy, horticulture, pharmaceutical botany and organic chemistry in terms of species identification, ornamental plant improvement and medicinal plant identification, respectively.

\section{Authors' contributions}

KK collected the plants, analyzed the data and drafted the manuscript. GWS planned the study, guided a taxonomic identification, provided important taxonomic literatures, revised the manuscript and polished the English. SCS guided lab work, revised the manuscript. PT suggested the study topic, collected the plants, planned the study, guided all lab work, revised and developed the manuscript, prepared the manuscript for submission. All authors read and approved the final manuscript.

\section{Author details}

${ }^{1}$ Department of Plant Science, Faculty of Science, Mahidol University, Rama VI Road, Ratchathewi, Bangkok 10400, Thailand. ${ }^{2}$ Herbarium, Royal Botanic Gardens, Kew, Richmond, Surrey TW9 3AE, UK.

\section{Acknowledgements}

The first author would like to thank the Science Achievement Scholarship of Thailand (SAST) and all members of the Plant Anatomy Laboratory, Department of Plant Science, Mahidol University. Special thanks to Mr. Sittinut Soonthornkalump for his kindness in allowing the authors to collect the samples from his land. Anja Buijsen, Botanical Library, Naturalis Biodiversity Centre, provided literature critical for this study. Traiperm wishes to acknowledge the TRF-RSA5880022 and the Faculty of Science, Mahidol University, for supporting this research.

\section{Competing interests}

The authors declare that they have no competing interests.

Received: 30 July 2016 Accepted: 21 September 2016

Published online: 28 September 2016

\section{References}

Abdel Khalik KN (2006) Seed morphology of Cuscuta L. (Convolvulaceae) in Egypt and its systematic significance. Feddes Repert 117:217-224

Abdel Khalik KN, Osman AK (2007) Seed morphology of some species of Convolvulaceae from Egypt (identification of species and systematic significance). Feddes Repert 118:24-37
Auddy B, Ferreira M, Blasina F, Lafon L, Arredondo F, Dajas F, Tripathi PC, Seal T, Mukherjee B (2003) Screening of antioxidant activity of three Indian medicinal plants, traditionally used for the management of neurodegenerative diseases. J Ethnopharmacol 84:131-138

Austin DF (2008) Evolvulus alsinoides (Convolvulaceae): an American herb in the old world. J Ethnopharmacol 117:185-198

Ayyanar M, Ignacimuthu S (2011) Ethnobotanical survey of medicinal plants commonly used by Kani tribals in Tirunelveli hills of Western Ghats, India. J Ethnopharmacol 134:851-864

Bridson D, Forman L (1999) The herbarium handbook, 3rd edn. Royal Botanic Gardens, Kew, London

Chen HW (2007) Pharmacognostical studies on Evolvulus species in Taiwan: (Evolvulus alsinoides and Evolvulus glomeratus). Master Class Thesis, China Medical University

Chen JH, Hang S, Yang YP (2008) Comparative morphology of leaf epidermis of Salix (Salicaceae) with special emphasis on sections Lindleyanae and Retusae. Bot J Linn Soc 157:311-322

Costea M, Ruiz IG, Welsh M (2008) A new species of Cuscuta (Convolvulaceae) from Michoacán, Mexico. Brittonia 60:235-239

Dettke GA, Waechter JL, Miotto STS (2014) Cuscuta taimensis (Convolvulaceae, Cuscuteae), a new species from South America. Brittonia 66:269-273

Erdtman G (1952) Pollen morphology and plant taxonomy. Angiosperms, 1st edn. Almqvist \& Wiksell, Stockholm

Erdtman G (1960) The acetolysis method, a revised description. Svensk Botanisk Tidskrift 54:561-564

Gunn CR (1969) Seeds of the United States noxious and common weeds in the Convolvulaceae, excluding the genus Cuscuta. Proc Assoc Off Seed Anal North Am 59:101-115

Hallier H (1893) Versuch einer natürlichen Gliederung der Convolvulaceen auf morphologischer und anatomischer Grundlage. Botanische Jahrbücher für Systematik 16:453-591

Hamed KA (2005) Pollen and seed characters of certain Cuscuta species growing in Egypt with a reference to a taxonomic treatment of the genus. Int J Agr Biol 7:325-332

Harms RT (2014) A new species of Evolvulus (Convolvulaceae) from the high plains of the Texas/New Mexico border. Phytoneuron 20:1-20

Hesse M, Halbritter H, Zetter R, Weber M, Buchner R, Frosch-Radivo A, Ulrich S (2009) Pollen terminology an illustrated handbook, 1st edn. SpringerVerlag/Wein, Berlin

Hsiao L, Kuoh C (1995) Pollen morphology of the Ipomoea (Convolvulaceae) in Taiwan. Taiwania 40:299-316

Johansen DA (1940) Plant microtechnique, 1st edn. McGraw-Hill Book Co., New York

Juan R, Pastor J, Fernandez I (1999) Morphological and anatomical studies of Linaria species from south-west Spain: seeds. Ann Bot 84:11-19 
Junqueira MER, Simão-Bianchini R (2006) O gênero Evolvulus L. (Convolvulaceae) no município de Morro do Chapéu, BA, Brasil. Acta Botanica Brasilica 20:157-172

Khare CP (2007) Indian medicinal plants an illustrated dictionary, 1st edn. Springer Science + Business Media, Heidelberg

Lau TC, Stephenson AG (1994) Effects of soil phosphorus on pollen production, pollen size, pollen phosphorus content, and the ability to sire seeds in Cucurbita pepo (Cucurbitaceae). Sex Plant Reprod 7:215-220

Lewis WH (1971) Pollen differences between Stylisma and Bonamia (Convolvulaceae). Brittonia 23:331-334

Manandhar NP (1985) Ethnobotanical notes on certain medicinal plants used by Tharus of Dang-Deokhuri District, Nepal. Int J Crude Drug Res 23:153-159

Menemen Y, Jury SL (2002) Pollen studies on some species of the genus Convolvulus L. (Convolvulaceae) from Morocco. Turk J Bot 26:141-148

Metcalfe CR, Chalk L (1950) Convolvulaceae. In: Metcalfe CR, Chalk L (eds) Anatomy of the dicotyledons, 1st edn. Clarendon Press, Oxford, pp 954-964

Naikawadi VB, Ahire ML, Lahiri A, Nikam TD (2016) In vitro propagation and cell cultures of memory tonic herb Evolvulus alsinoides: a best source for elicited production of scopoletin. Appl Microbiol Biotechnol 100:3463-3476

Perveen A, Al-Alawi AH, Husain SZ (1989) A contribution to the palynological survey of the genus Convolvulus from South West Asia and Arabian Peninsula. Pak J Bot 21:197-209

Pisuttimarn P, Traiperm P, Pornpongrungrueng P (2013) Comparative anatomy of Merremia section Xanthips (Convolvulaceae) in Thailand (in Thai). In: Proceeding of NGRC 29th The National Graduate Research Conference, Chiang Rai, Thailand, 24-25 October 2013

Quisumbing EA (1978) Medicinal plants of the Philippines. Katha Publishing Co., Philippines
Rajurkar AV, Tidke JA, Patil GV (2011) Studies on pollen morphology of Ipomoea species (Convolvulaceae). Res Plant Biol 1:41-47

Rao SR, Leela M (1993) Seed morphology (LM and SEM) in some Ipomoea L. (Convolvulaceae. Feddes Repert 104:209-213

Robertson KR (1982) Odonellia, a new genus of Convolvulaceae from tropical America. Brittonia 34:417-423

Sarma K, Tandon R, Shivanna KR, Mohan Ram HY (2007) Snail-pollination in Volvulopsis nummularium. Curr Sci 93:826-831

Sayeedud-Din M (1953) Observations on the anatomy of some of the Convolvulaceæ. Proc Plant Sci 37:106-109

Singh KP, Dhakre G (2010) Reproductive biology of Evolvulus alsinoides L. (medicinal herb). Int J Bot 6:304-309

Staples G (2010) Convolvulaceae. In: SantisukT, Larsen K (eds) Flora of Thailand vol 10(3). Prachacohon, Bangkok, pp 330-468

Staples G, Traiperm P, Chow J (2015) Another New Thai Argyreia Species (Convolvulaceae). Phytotaxa 204:223-229

Stuessy TF (2009) Plant taxonomy the systematic evaluation of comparative data, 2nd edn. Columbia University Press, New York

Tayade SK, Patil DA (2012a) Anatomical studies of stem in some Convolvulaceae. Lisper 1:42-46

Tayade SK, Patil DA (2012b) Leaf anatomical studies in some species of Convolvulaceae. Life Sci Leafl 3:64-74

Tellería MC, Daners G (2003) Pollen types in Southern New World Convolvulaceae and their taxonomic significance. Plant Syst Evol 243:99-118

van Ooststroom SJ (1934) A monograph of the genus Evolvulus. Mededeelingen van het Botanisch Museum en Herbarium van de Rijks Universiteit te Utrecht 14:1-267

Welsh M, Stefanović S, Costea M (2010) Pollen evolution and its taxonomic significance in Cuscuta (dodders, Convolvulaceae). Plant Syst Evol 285:83-101

\section{Submit your manuscript to a SpringerOpen ${ }^{\odot}$ journal and benefit from:}

- Convenient online submission

- Rigorous peer review

- Immediate publication on acceptance

- Open access: articles freely available online

- High visibility within the field

- Retaining the copyright to your article

Submit your next manuscript at springeropen.com 